Aberdeen and in the Shetlands, all on the continuation of this line, were not improbably related to the same general cause, though the continuity of the advance of the original system cannot be verified.

The main rainfall was confined to a belt between 30 and 40 miles in width, lying along the track of the storm. In this zone, falls were probably everywhere greater than $I$ in., at least as far north as the Wash, while they equalled 2 in. in many places, and reached 3 in. in isolated patches. On the south coast this belt of heavy rain extended from a point between Worthing and Brighton to a point between Eastbourne and Hastings, while central London lay in the middle of the affected zone. Outside this band, amounts fell off quickly, particularly on the eastern side, where the boundary was sharply defined; for example, while Eastbourne received $\mathrm{I}_{\frac{3}{4}}$ in., Hastings and places further east escaped rain, and while Tunbridge Wells experienced nearly an inch, there was none at Maidstone.

Over the southern portion of the track, including London, rain fell practically continuously for more than 6 hours, so that, allowing the speed of 25 miles per hour, the main travelling rain system responsible for this belt of precipitation was here probably about I 50 miles long in the direction of its motion, and 35 miles broad.

In the north, the amounts and duration of rainfall appear to have been rather less than in the south of England.

Striking agreement in time is shown by the hyetograph and microbarograph records at South Kensington between sudden changes of pressure and intense bursts of rain, particularly just after 2 A.M. (G.M.T.). There is also agreement between the sudden changes of pressure at South Kensington and those recorded at Kingsway, London, W.C.2, by the Dines float barograph, which shows the absolute magnitude of the pressure changes. It is interesting to mention that an observer in Hampstead noted quite independently that the worst crashes, followed immediately by torrential rain, occurred at 2.I5 A.M. and 3.45 A.M. (G.M.T.). The first of these was about ro minutes after the occurrence of the very pronounced peak in the Kensington microbarograph record and corresponding heavy rain shown by the hyetograph record. Thus, allowing 4 miles between the places of observation, we again find phenomena associated with the storm travelling at about 25 miles per hour.

Although a closer investigation is desirable before putting forward an explanation of the storm with full confidence, an examination of the weather charts and upper air data available brings to light some very suggestive facts. Measurements of upper winds on the evening before the storm show that between about 6000 feet and 18,000 feet above the surface there was a general wind current over the affected area agreeing very closely indeed in direction and speed with those of the movement of disturbance itself, and observations of the drift of cirrus cloud show that above this the air motion was probably from about S.W. Now the weather charts for July 8 and 9 show an anticyclone over the Continent and a depression almost stationary off the West of Ireland, and, further, a current of air of undoubtedly polar origin, and therefore probably having a low upper-air temperature, circulating round the latter.

It seems very likely that some of this polar air, in arriving, at some upper level, over the south-west districts of England and endeavouring to work its way northwards, side by side with the very warm air of continental origin over the eastern districts, spread laterally over the latter, producing the travelling area of instability necessary to explain the phenomena described above.
M. A. GibletT.

\title{
The Pascal Commemoration on the Puy de Dôme.
}

TH IE tercentenary of the birth of Blaise Pascal (born June 19, 1623, died August 19, I662) was celebrated at Clermont-Ferrand in a series of fêtes at which the President of the French Republic, M. Millerand, and the most distinguished French scholars and philosophers met to do homage to his great genius.

The culminating interest of the celebrations was the visit to the summit of the Puy de Dôme on Sunday, July 8 , to commemorate the experiment devised by Pascal and carried out successfully by his brother-in-law Florin Périer, an experiment as famous in its day and as decisive in its significance as the eclipse expedition of May I9r9 has proved to be in our day. In demonstrating that the atmosphere has weight it destroyed a principle of the old physics which had become authoritative, the principle that Nature abhors a vacuum, and at the same time it inaugurated a new scientific concept in physics. The rain poured as we gathered on the summit where, above the ruins of an ancient temple of Mercury, a modern meteorological observatory has been erected. Those who were so fortunate as to find room in the small cupola of the observatory, however, are not likely to forget M. Painlevé's discourse. Round the President were grouped the Prefects of the Departments, the Mayor of Clermont, the Rector of the University, Senators and Deputies, the representatives of the Institut de France, and the foreign guests of the Municipality. In an eloquent oration M. Painlevé described the inception of the great experiment and discussed its significance.
No one of that large company (the Municipality entertained three hundred guests at the déjeuner on the mountain) who had ascended the mountain by the modern means of electric traction with luxurious comfort in little more than an hour can have failed to reflect on the different conditions which prevailed in Pascal's time, and on the enormous difficulties of the original expedition. Those who are interested may read the full and careful report of it in Périer's letter to Pascal. It was arranged that first of all two sets of apparatus should be tested side by side to see that they gave identical measurements, that is, to see that each column of mercury in the inverted tubes (barometer tubes) remained at the same height. One set was then carried up to the top of the mountain and the other left behind in the church of the Minimes at Clermont. The experiments with each set were made at the prearranged hour and precisely recorded. The significance of the experiment was its uniqueness. It differed entirely from observations which any one might make with the scientific intention of recording facts; it differed entirely, for example, from observations such as those of Tycho Brahe. It was uniquely designed to test a physical theory which would stand or fall by the result. It had been known practically by engineers for a long time that there was a natural limit to the action of a pump, and in the crucial experiment of Torricelli with the column of mercury in the glass tube closed at one end and immersed in liquid at the other it was shown that the principle was

No. 2803 , vOL. I I 27 
the same as that which was applied to the action of pumps, with the difference presumably due to the density of the liquid.

The problem was not the fact but its significance. The Aristotelians held that it had been definitely established that the atmosphere had no weight, and what is quite certain is that no means of discovering its weight, if it had any, then existed. It is therefore strikingly analogous to the case of the hypothetical ether when physicists were engaged in devising means of revealing its presence. Descartes, though entirely opposed to the Aristotelians, yet held on a priori grounds that the universe was a plenum. He needed the concept in order to explain the vortex motion which in his view accounted for the variety of material forms. The apparent vacuum in the Torricelli tube he supposed to be due not to an absence but to the presence, or rather to the entrance under the conditions of the experiment, of a very subtle matter. Pascal, on the other hand, to quote M. Painlevé, " s'inspirant de Galilée et Torricelli, entre la science d'Archimède et la science moderne, jette un pont par-dessus vingt siècles. La presse hydraulique, le baromètre observé à diverses altitudes, ce sont les illustrations d'une statique nouvelle qui embrasse à la fois, dans les mêmes principes, l'équilibre des liquides et celui des gaz." Let us imagine, he went on to say, that through some disaster everything which we now know about Pascal had been lost to us save only his scientific writings. In what light would he appear to us ? We should be right to point him out as the first of the positivists methodically disengaging facts from the confusion of words, discrediting purely verbal definitions, " cet air subtil qui aurait des inclinations," " cette lumière qui est un mouvement luminaire de corpuscules lumineux."

Other memorable discourses followed, in particular one by M. Picard, before we sat down to the sumptuous banquet which the Municipality offered its guests. When this was concluded the President of the Republic rose and to the enthusiastic applause of the company, though, it must be admitted, to the general surprise of those who were thinking of Pascal, delivered an impassioned and truly eloquent speech on the politics of the hour, which was immediately transmitted round the world. The rain ceased, and we made the return journey to Clermont favoured by a clear sky and splendid view over the grand Auvergne country. The city was gaily decorated for another celebration in the square over which the statue of the seated Pascal presides.

H. WILDON CARR.

\section{An Advance in Photometry.}

HERR E. STEINKE, in an investigation into the accuracy of the Wien-Planck law in the ultraviolet region of the spectrum, has recently made use of Elster and Geitel's potassium photo-electric cell, as neither the thermopile nor the bolometer was sufficiently sensitive to measure the minute quantities of radiant energy involved (Zeits. f. Physik., II. 4 and 5 , pp. 215-238, I922).

Herr Steinke has found it possible to increase the sensitiveness of the cell enormously, by increasing the voltage between the potassium anode and the platinum cathode; and has carefully investigated the behaviour of the cell under these conditions. For red light, $\lambda=630 \mu \mu$, an increase in voltage from 20 to 2 ro multiplies the sensitiveness by 1045, and for violet light, $\lambda=462 \mu \mu$, by 1595 . This is due to the increased ionisation from collisions between the greatly accelerated electrons and the argon contained in the cell.

No. 2803 , voL. 1 I 27
It was not possible to apply such a high voltage to the cell suddenly without a luminous discharge; it was necessary to raise it gradually for hours or even days at a time, and it was then possible to reach the 2 Io volts already mentioned. At 2 I 2 volts luminous discharge took place, after which the cell discharged at 162 volts, recovering if left to itself for some days, so that the potential could again be raised to 200 volts. In forming the cell, as above, for high voltages it was found that each time the voltage was increased there was a strong "darkness" current at first; which diminished in the course of time to zero for lower voltages, and at 2 Io volts to a moderate value after several days.

When the cell is prepared in this way, and is illuminated, a fatigue effect is observed, the time required for the thread of the Lutz-Edelmann electrometer to move from a certain division on the scale to another ( 85 to 65 ) gradually increasing to a limiting value, which in one experiment was reached in about fifteen minutes. This limiting value was determined in all the experiments. These were always made in the order of increasing illumination, as it was found that a high illumination produced a kind of after action, and a small illumination measured shortly afterwards showed a higher value than the real one. For the high voltages employed the limiting value of the photo-electric current was not proportional to the illumination, as it was found to be by Elster and Geitel for moderate voltages; but the following relation was proved to exist, $\mathrm{I}^{z}=\mathrm{ML}$; where $\mathrm{I}$ is the photo-electric current, $\mathrm{L}$ the flow of radiant energy, and $z$ and $\mathrm{M}$ are constants. The cell constant $z$ varies with the wave-length, and with the voltage applied to the cell; for small voltages it scarcely differs from unity, and the law becomes identical with that of Elster and Geitel ; for $\lambda=3 \mathrm{I} 6 \mu \mu$ $z$ was observed to be I'3495, with 208 volts on the cell terminals, and intermediate values were found for other wave-lengths and voltages.

Using the method described, Herr Steinke has measured the exponent $c_{2}$ in Planck's formula $\mathrm{E} \lambda=\frac{\mathrm{C}}{\lambda^{5}} \frac{\mathrm{I}}{e^{c_{2} / \lambda \mathrm{T}}-\mathrm{I}}$ for a number of different wave-lengths, including $340 \mu \mu$ and $316 \mu \mu$ in the ultra violet. The mean value is 14,385 , the largest variation from this being 0.63 per cent., and the mean probable error 0.16 per cent. The actual probable error is rather greater than this, owing to the difficulty of determining the wave-length of the rays employed, which were separated from the light of a carbon incandescent lamp by filters. The value agrees satisfactorily with that determined by previous observers for vistble radiations. The observations also show that carbon radiates, throughout the range of wavelengths investigated, as a grey body. Herr Steinke proposes to continue the investigation, and to measure the constant $\mathrm{C}$ in the above formula.

It would appear that the improved method of using the photo-electric cell should prove of the highest value in work on the spectrum, particularly in the ultra violet.

\section{International Conference on Nature Reserves.}

THREE Associations in France entitled, respectively, the Société Nationale d'Acclimatation de France, the Ligue Français pour la Protection des Animaux, and the Société pour la Protection des Paysages de France, recently invited the Royal Society for the Promotion of Nature Reserves to send delegates to attend a conference "Pour la Protection de la 